УДК 811.163.3'373.7

ДОИ https://doi.org/10.18485/primling.2016.17.7

\author{
Драгана Кузмановска \\ Снежана Кирова \\ Биљана Иванова \\ Филолошки факултет \\ Универзитет „Гоце Делчев“ \\ Штип, Р. Македонија
}

\title{
РАЗГРАНИЧУВАЮЕ НА ИДИОМИТЕ И НА СЛОБОДНИТЕ ФРАЗИ
}

\begin{abstract}
Апстракт: Идиомите како постојани фрази, по правило, имаат строго одредени и само во ограничени рамки променливи структури. Како предмет на нашево истражување го поставуваме прашањето за нивното можно одделување од неидиоматичните слободни фрази преку користење на методот на интроспекција и анализа на дадениот корпус на фрази од германскиот, англискиот и македонскиот јазик. Со овој труд ќе се обидеме да дадеме одговор на неколку прашања од кои најзначајни се: „Како тие најсигурно можат да се одделат од неидиоматските слободните фрази?““ и „Како би биле класифицирани?“.
\end{abstract}

Клучни зборови: разграничување, фрази, идиоми, постојани, составни делови.

Фразите, идиомите, постојаните фрази, идиоматските изрази, зборообразувачките лексеми, фразеологизмите и фразеолошките лексеми се ознаки со кои се користи науката за јазикот за да ги опфати одредените говорни појави, кои не можат да се запишат како „преформулирани“, ни како слободни зборовни синџири, туку како еден вид „готови говорни составни делови“ (Велковска 2002:15).

Како пример ја наведуваме реченицата „Sie hat ihm einen Bären aufgebunden” (Таа го товари со мечка) која според наведениот превод е неразбирлива, затоа што е резултат сумиран од поединечните значења на зборовите од кои се состои не земајќи го предвид нејзиното прифаќање како готова фраза (DUDEN 2002:9). Доколку се размисли малку подлабоко, ќе се дојде до сознанието дека станува збор за фразата ,jemandem einen Bären aufbinden“ која има целосно определено значење „Sie hat ihn dazu gebracht, etwas Unwahres zuglauben. (Таа го наведува да верува во нешто невистинито)“(DUDEN 2002:9). Преку наведениот пример се обидуваме да ја оправдаме потребата од појава на еден ваков труд со наслов Разіраничување на иолмите ияиоми и слобояни фрази. 
Кога зборуваме за идиоми и фрази, пред сѐ, треба да имаме на ум дека тие се составени од повеќе од еден збор, но во секојдневната употреба на јазикот како фрази може да се сретнат и единични зборови како „Ulknudel“ (интересен човек) или „grottendoof“ (глупав). Потоа треба да запомнема дека кај овие видови на зборовни групи едно многу важно обележје е дека крајното значење го нема или делумно го има поединечното значење од составните делови на таа зборовна група и дека таа по правило има строго одредена и само во ограничени рамки променлива структура. Наша идеја и цел во овој труд е да се обидеме да ги разграничиме ваквите зборовни групи наречени идиоми од т.н. неидиоматски слободните фрази.

За да направиме дистинкција помеѓу наведените зборовни групи потребно е најпрвин да дадеме објаснување на поимот значење, односно т.н. „сложено“ значење. За таа цел поаѓаме од следните примери:

1. „Der Junge hat lange Finger gemacht = hat gestohlen“ (краде);

2. „Der Junge hat gute Fortschritte gemacht“ (направи добар напредок) (DUDEN 2002:9).

Од наведениве примери јасно се гледа дека постои голема разлика во однос на значењето и тоа дека во првиот пример станува збор за т.н. „сложено“ значење затоа што значењето не одговара на значењата на поединечните зборови, што значи дека станува збор за идиом. Во вториот пример имаме т.н. неидиоматска фраза затоа што значењето на реченицата претставува збир од поединечните значења на сите зборови во неа. Од наведеново може да заклучиме дека во однос на значењето идиомите имаат не-буквално значење за разлика од слободните фрази кои имаат т.н. буквално значење. Но, би било погрешно од ова да се заклучи дека сите не-буквално употребени фрази се идиоми. За ова говорат следните примери:

1.Das ist ein dicker Hund! (Ова е една зачудувачка работа/ голема дрскост);

2.Das ist ein elender Hund! (Ова е еден злобен човек) (DUDEN 2002:9).

Примериве укажуваат на фактот што и во двата случаи имаме фрази кои може целосно буквално да се разберат како искази за едно куче, така што во повеќето ситуации „еin dicker Hund“ може да се разбере како „еine erstaunliche Sache“ (зачудувачка работа) или како „eine große Frechheit“ (голема дрскост), додека пак за „ein elender Hund“ се мисли на „ein niederträchtiger, bösartiger Mensch“ (еден подол, злобен човек). Разликата помеѓу двете спојувања се однесува на тоа што во првиот случај зборот „Нund“ (куче) само во спој со зборот „dick“ (дебел) може да се употреби за изразување на изненадување и разгневување - формите како „ein schlimmer Hund“ (лош човек) или „ein staunlicher Hund“ (импресивен човек) би можеле овие значења исто така да се заменат со „ein dicker Hase“ или „ein dicker Kater“ (дебел зајак / мачор). Во вториот случај, според тоа, може да стои зборот „Нund“ самостојно или поврзан со други придавки за „schlechter Mensch“ (лош човек) како што се „du Hund!“” (ти куче!), „dieser gemeine Hund!“ (ова просто куче), „ein hinterhältiger Hund“ (подмолно куче) итн. Исто така, и зборот „еlend“ (беден) е како обезвреднета придавка слободно употребена, на пр. во „еin elender Schuft“ (беден подлец) или „diese elende Betrüger!““ (овој беден преварант).

Постојаните фрази или идиомите можеме да ги сретнеме најчесто како метафори затоа што, пред сѐ, поетскиот јазик е оној кој се приклонува кон тоа да зборовите се употребуваат на поинакви начини и на тој начин да се создаваат нови 
начини. Исто така, треба да се знае дека идиомите се сепак издвоени од оние настанатите поетски метафори. За ова говорат следните примери:

1.Der goldene Mittelweg. (адекватното решение);

2.Das goldene Himmelsfeuer. (златниот небесен оган) (DUDEN 2002:10).

Повторно првата од двете фрази е идиом, а како постојано анализирано: „Der goldene Mittelweg“ значи „eine angemessene, vermittelnde, die Extrememeidende Lösungeines Problems, eines Konflikts“ (адекватно, посредувачко, екстремно избегнувачко решение на проблемот, на конфликтот). Вториот синџир од зборови би можел да се разбере како на пр. парафразирање за сонцето. Со "mit dem goldenen Himmelsfeuer" (со златниот небесен оган) би можело да се мисли на добра рефлексија на отсјај или на огномет, сонцето се однесува, исто така, и како „golden glänzendes Himmelsfeuer oder Goldenes Himmellicht“ (златно сјаен отсјај или златно небесно светло) како многу други видови. „Ein goldglänzender Mittelweg oder eine goldene Mittelalleе“ (златно сјаен значаен или златна централна област) не се поистоветуваат со горе наведеното значење.

Вистинската фраза наспроти метафората е слободно сликовито парафразирање, јасно посветено на одредено значење.

Од друга страна, таа многу малку или воопшто не варира во однос на нејзините составни елементи, додека пак метафората може дури и произволно да варира.

Според историјата на јазикот често се случува да една денешна строго определена фраза настанала од метафора, која со текот на времето се фиксира во една определена форма и се здобива со одредено значење.

Друго обележје кое е карактеристично за идиомите наспрема слободните фрази е променливоста. Во однос на ова обележје треба да напомнеме дека многу од зацврстените фрази, односно идиоми, се противат на една цела низа на синтаксички или други операции, кои кај слободните зборовни групи се можни однапред.

Поединечните зборови во неидиоматските фрази: „еin Mann und eine Frau“ (еден маж и една жена) можат да се заменат делумно или целосно со „Ein Mann und eine weibliche Wesen“ (еден маж и едно женско битие). Во науката за јазикот ова се нарекува замена или супституција. Дури може да се додаде објаснувачки додаток или блиско дообјаснување на еден или на повеќето зборови во ваквите неидиоматски фрази: „Еin Mann und eine schöne Frau“ (еден маж и една убава жена) и тогаш станува збор за атрибуција или додавање. Поврзувањето може да се прошири на еден или на повеќе зборови: „Еin Mann und unter Umständen auch eine Frau“ (еден маж и под одредени околности и една жена), односно да стане збор за дискотинуитет или прекин. Кога пак се преместуваат или заменуваат местата на зборовите: „eine Frau und ein Mann“ (една жена и еден маж) тогаш станува збор за пермутација или преместување. И на крајот, може да мутираат формите на зборовите на пр. може именките да бидат во множина: „Männer und Frauen“ (мажи и жени) значи да претрпат морфолошки измени или промена на формите. Значи слободно можеме да заклучиме дека кај слободните зборовни групи „еin Mann und eine Frau“ (еден маж и една жена) се можни сите овие операции без последица на јазичните чувства. Сите ново формирани зборовни групи се, исто така, прифатливи како и почетните форми.

Кога пак станува збор за другата категорија на зборови какви што се зацврстените фрази или идиоми ситуацијата е поинаква. Примерот ќе ни укаже на мож- 
ните разлики во однос на слободните фрази: „Mit Mann und Maus untergehen“ (сите пропаѓаат/ нема преживеани). Доколку се направат истите операции со оваа фраза како со горенаведените ќе се добијат следниве комбинации:

Замена: „Mit Mann und Nagetier untergehen.“ ;

Атрибуција: „Mit Mann und kleiner Maus untergehen.“;

Дисконтинуитет: „Mit Mann und unter Umständen auch Maus untergehen.“;

Пермутација: „Mit Maus und Mann untergehe.“;

Морфолошки измени: „Mit Männer und Mäusen untergehen.“ (DUDEN 2002:10).

Сите овие случаи еден компетентен германски говорител би ги сметал за погрешни или пак за невообичаени. Тој веднаш ќе се асоцира на „вистинските“ форми „Mit Mann und Maus untergehen“ (сите пропаѓаат), а изведените форми ќе ги прифати како игра на зборови или како сакани варијации на вообичаените идиоми. Како заклучок од наведеното треба да се забележи дека опишаните операции се во основа неприфатливи за вистинските идиоми, но не и невозможни (Friedrich 1976:6).

Атрибицијата, на пример, е можна кај идиомот „Wert auf etwas legen = großen Wert auf etwas legen“ (придава големо значење), дисконтинуитет или пермутација се можни во поширока мера, пред сѐ, кај глаголските идиоми и тоа кај „etwa bei Kohldampf schieben $=$ wir schieben seit Tagen Kohldampf“ (да се биде изгладнет). Исто така, и морфолошките измени не се исклучени во повеќето случаи „,blinder Passagier = die blinden Passagiere“" (слепи патници).

За разлика од претходно опишаните операции замената по правило не е или е можна само во многу ретки случаи. За спојот „wie aus dem Ei gepellt“ (цаком паком) постои варијантата „,wie aus dem Ei geschält“, но варијантата „wie aus dem Hühner Ei gepellt“ (како од кокошки снесено јајце) го нема истото значење. Замената, односно комутацијата, и тестот за замена на зборовите во повеќето случаи се сигурен начин за ограничување на вистинските идиоми.

Кога зборуваме за ограничување треба да имаме предвид дека станува збор за повеќе видови на ограничувања меѓу кои е и делумната лимитирана заменливост. Во близина на зацврстените фрази/ идиоми, но се разбира од овие ограничените, се наоѓаат зборовни групи чии дистинктивни белези лингвистот Еугенио Косериу (Eurenio Coseriu) ги означил како ,lexikalische Solidarität“ (лексичка солидарност) (Eugeniu/ Horst 1981:43). Пример за овие фрази е „der späte Hölderlin“ (во најпродуктивните творечки години) во реченицата „Der späte Hölderlin hat keine Liebesgedichte mehr geschrieben“ (Во неговите најпродуктивни творечки години не пишувал повеќе љубовни песни). Само со атрибутивниот спој со името на познатиот творец се употребува придавката „,spät“ со значење „in seinen letzten Lebens- und Schaffensjahrenstehend“ (во неговите најпродуктивни творечки години). „Нӧlderlin“ (Холдерин) во овој контекст не ќе може да се замени со „Briefträger“ „Großvater“ (поштар, дедо), туку би било можно да се замени со „Goethe“, , Shakespeare“ (Гете или Шекспир). Постои и една цела класа на зборови кои се карактеризираат по одредени значења, според која придавка „spät“ во горенаведената смисла ќе може да се комбинира без лимитирање или ограничување од страна на заменливоста. Истото важи и за глаголот „bellen“ кој во неговото конкретно значење по правило се однесува на носителот на дејството „Нund“ (куче), овие повторно како една цела класа 
на зборови се елементи кои се заменливи, на пример, во реченицата „Der Hund/ Pudel / Rüde / Jagdhund / Dackel beelt.“ (Кучето/пудлицата/кучиштето/загарот/јазовичарот лае). На зацврстените фрази, односно на идиомите, ваквите замени не им се познати, односно не им се својствени или не ги препознаваат, од што произлегува и следнава констатација дека реченицата „Mich laust der Affe!““ (По ѓаволите!) не се заменува со „Mich laust der Gorilla/ das Affenweibchen!“‘ (Friederich 1976:17).

Ограничување кај зацврстените фрази односно кај идиомите имаме и во однос на глаголите со предлози. Ограничени се висинските фрази, исто така, и од споевите од глаголи со определени предлози, кои се значајни особено во наставата по странски јазик (Кузмановска 2014: 65) . Зборот „glauben“ (мисли), на пример, во германскиот јазик може да означува и предлошки објект во спој со предлогот „,an“ (на): „Er glaubt an Geister.“ (Тој мисли на духот) (DUDEN 2002:11). Значењето на „an etwas glauben“ (мисли на нешто), не исклучувајќи го поширокото значење на „an“ и на „glauben“, се однесува во поголем број случаи на просторни и временски услови и овој вид на споеви можеме теоретски да ги вброиме во зацврстените фрази. Земајќи предвид дека значењето на еден предлог често е тешко егзактно да се определи и дека во повеќето вакви споеви глаголот не отстапува или многу ретко отстапува од неговото значење, тогаш изгледа дека во ваквите случаи, како што вели науката, станува збор за реакција на глаголи. Се опишува глаголот „glauben“ поврзан со дативен објект „Ich glaube ihm“ (мислам на него), со акузатив објект „Ich glaube die Geschichte“ (и верувам на историјата), со предмет реченица „Ich glaube, dass es wahr ist“" (мислам дека е вистина), и на крајот со предлошки објект ,an + Akk. “ „Ich glaube an böse Geister“ (верувам во лоши духови) (DUDEN 2002:12).

Следното ограничување се однесува на стереотипните споредби, затоа што е забележана една несомнено помала дистинкција на вистинските и на слободните зборовни групи во областа на формите за споредување. Слободните споредбени образувања се во неограничен број можни, како на пример „sie war stark wie ein Pferd, er schnaufte wie ein Dampflokomotive usw.“ (Таа е силна како коњ, тој чади како парна локомотива итн.). Некои од можните споредби се толку често употребувани што преминале во стереотипи. Понекогаш остануваат како споредбени во јазикот кога со текот на развојот на самиот јазик поединечните елементи го губат нивното сопствено значење. Зошто, на пример, зборот „Bohnenstroh“ треба да ја објаснува особината „dumm“ (глупавост) и денес се сретнува кај фразата „dumm wie Bohnenstroh sein“ (толку е глупав што не знае слама на два вола да подели) за чие објаснување потребно е навраќање наназад во историјата на јазикот (Friederich 1976:63). При таквото навраќање наназад во историјата наидуваме на старата форма „grob wie Bohnenstroh sein“, која се однесува на сиромашни и необразовани луѓе, кои нивниот кревет не можат да си го постават на вистинското лежиште и затоа мора да употребат поголеми и груби лисја од зрната на добиточната храна, а дури подоцна со текот на времето „grob“ (груб, прост) ќе го добие денешното значење „dumm“ (глуп). За разлика од таквите вистински форми за споредба, односно стереотипните споредби како „weiß wie Schnee oder zart wie Samt“ (бел како снег или нежен како кадифе) припаѓаат во тесната област на зацврстени фрази, така што тие се покажуваат како релативно тешко променливи во комуникациските варијанти „weiß wie ein Schwan, weiß wie frisch gefallener Schnee, wie Schnee so weiß“ (бел како лебед, бел како свежо 
паднат снег, толку бел како снег). Од наведеново слободно можеме да заклучиме дека едно строго шематско разграничување овде е тешко возможно, зошто степенот на идиоматската цврстина во случаите: ,, schnell wie der Blitz oder hungrig wie ein Wolf“ (брз како блиц или гладен како волк) може различно да се процени (DUDEN 2002:12).

Исто така, не е строга и границата помеѓу зацврстените фрази во областа на т.н. функционални глаголски фуги (Schemann 1993:8). Тоа се соединувања на глагол настанат од именка со друг глагол, кој во ова соединување го губи своето вистинско значење. Значењето на функционалната глаголска фуга по правило се совпаѓа повеќе или помалку со значењето на глаголот од кој е изведена именката, како на пример „eine Entscheidung treffen“ значи исто како и глаголот: ,entscheiden“ (одлучува), ,zur Verteilung gelangen“ значи „,verteilt werden“ (распределува). Со одредени глаголи може да се создадат голем број на вакви фуги, односно спојувања, на пример со глаголот „,bringen“ (донесува) во примериве „zur Verteilung bringen, zur Entfaltung bringen, zum Abschluss bringen...“ (распределува, развива, завршува), така што според ова може да се каже дека генерално не постојат повеќе ограничени можности за заменување кога станува збор за зацврстените фрази. Повеќето јазични критичари и негувачи на јазикот сметаат дека функционалните глаголски фуги се непотребна категорија затоа што текстот единствено ги забележува новосоздадените формулации Исто така, и кога во одредени ситуации би можеле да имаат значенско диференцирана функција како во примерот „etwas in Ordnung bringen“ (доведува нешто во ред) што не е исто со „еtwas ordnen“ (подредува нешто) дури и тогаш важат како втиснати начини на изразување карактеристични за уредничкиот стил (Friederich 1976:351).

Една понатаму неопходна но не секогаш јасна граница се однесува на групата на зацврстени атрибуции (спој од придавка и именка). Додека кај „tote Hose, heißes Eisen oder blinder Passagier“ (смртно досаден, врел костен или слеп патник) кај кои најмалку еден елемент не е заменлив со друг и затоа се сметаат за зацврснати фрази, но има и многубројни случаи како во ,,armes Würstchen, armes Schwein, kleines Würstchen, lächerliches Würstchen usw.“ (ситна душа), во кои и двата елемента се заменливи и кои поради ова не се разгледуваат како зцврснати фрази во потесна смисла на зборот, иако тие најчесто интуитивно се подредуваат во оваа област.

\section{Заклучок}

Со овој труд ние се обидовме да ги наведеме и образложиме пречките кои се јавуваат при одредувањето на строгата граница помеѓу зацврстените фрази односно т.н. идиоми и слободните фрази во јазикот, притоа користејќи примери од германскиот јазик. Од досега наведеното слободно можеме да констатираме дека една ваква строга граница помеѓу наведените фрази не е возможна, затоа што имаме повеќе показатели кои стојат на просторот помеѓу двете категории и не дозволуваат да се постави односно точно да се дефинира строга граница помеѓу идиомите и слободните фрази, но тоа не значи дека и не постои воопшто граница помеѓу нив (Кузмановска 2014:42). Во трудот се обидовме да ги презентираме нашите сознанија и согледувања во однос на овој проблем наречен разграничување на идиомите и слободните фрази и се надеваме дека барем дадовме едно солидно согледување на состојбата помеѓу идиомите 
и слободните фрази која понатаму ќе им послужи на љубителите на лингвистиката и секако на јазикот да може да се снајдат во лавиринтот од фрази и точно и прецизно да ги дефинираат односно да ги разграничат овие две категории на фрази кои, според нас, се од големо значење за збогатувањето на јазичниот дискурс на еден лингвист, на еден ученик, на еден учител, на еден љубител на јазикот. Се надеваме дека со овој труд ќе поттикнеме уште многу други истражувачи кои ќе навлезат подлабоко во оваа сфера и ќе дадат поголем придонес во науката за јазикот.

\section{ЛИТЕРАТУРА}

Велковска, С. (2002). Белешки за макеgонскайа фразеолойија. ИМЈ. Јазикот наш денешен. кн. 8. Скопје;

Кузмановска, Д. (2014): Пословици и поговорки со анимална компонента во германскиот и во македонскиот јазик. Филолошки факултет, Универзитет „Св. Кирил и Методиј“ Скопје (Unpublished).

Friedrich, W. (1976). Moderne deutsche Idiomatik. Alphabetisches Wörterbuch mit Definitionen und Beispiele. 2 neubearbeitete Auflage. Max Hueber Verlag. München;

DUDEN (2002): Redewendungen: Wörterbuch der deutschen Idiomatik (Duden Deutsche Sprache in 12 Bänden);

Eugeniu, C and Horst, G (1981): Trends in structural semantics. (Tübinger Beiträge zur Linguistik, 158). Tübingen.

Schemann, H. (1993): Deutsche Idiomatik, Die deutschen Redewendungen im Kontext. Stuttgart: Ernst Klett Verlag für Wissen und Bildung ;

\section{Dragana Kuzmanovska Snezana Kirova Biljana Ivanova}

\section{DISTINGUISHING IDIOMS AND FREE PHRASES}

Summary: Idioms, being permanent phrases, as a rule have strictly determined and only in certain limited frames variable structures. The subject of our study is the question of their possible separation from free non-idiomatic phrases by using the method of introspection and analysis of the given corpus of phrases from German, English and Macedonian. The research so far has been bilingual, but we will perform the analysis of the phrases in the three listed languages, in order to determine whether there are more similarities than differences among these phrases in different languages. The fact that their meanings do not have or only partially have the individual meanings of their constituents is taken as their key feature. With this paper we try to give answers to several questions the most important being: "How can they, in a most certain way, be distinguished from free non-idiomatic phrases?" and "How would they be classified?".

Key words: distinction, phrases, idioms, permanent, constituent parts. 